\title{
INTERCONNECTEDNESS OF WOMAN AND NATURE WITH SPECIAL REFERENCE TO WOMAN CHARACTER NANDA KAUL IN ANITA DESAI'S FIRE ON THE MOUNTAIN
}

Anjali Daud Parmar

Prof. Ami Upadhyay

\begin{abstract}
The paper focuses on the changing trends in Indian writing in English with special reference to Anita Desai. During the seventy years of its effective history Indian writing in English crossed many milestones and has come to be finally accepted as a major literature of the world. A new group of writers have arrived on the Indian scenario, for example - Anita Desai, Chaman Nahal, Kamala Markandaya, Arun Joshi,Dina Mehta, Salman Rushdie, Shobha De, Vandana Shiva, and the Booker Prize winner Arundhati Roy and many more in list. Here I would like to focus on the new trend in Indian literature and that is ecofeminism as well as her portyal of woman characters in that context. A close reading of Anita Desai and her novels makes us aware of her novel is related to her own experiences and the reality. Attention on this work is focused on the life of Anita Desai, her interest in ecofeminism and how she is influenced by social, economic, political and cultural problems of her age.
\end{abstract}

\section{Introduction}

Feminism is an ideology which seeks not only to understand the world but to change it to the advantage of women. Simon De Beauvoir opines that women's idea of herself as inferior to men and depended on him springs from her realization that, "the world is masculine on the whole, those who fashioned it, ruled it, and still dominate it today, are Men." The biological distinction between man and woman is a very fact which is accepted by women. But the notion that woman is inferior to man is not accepted to woman in general as well as the feminists particular. 
As far as Anita Desai is concerned, she writes mostly about the miserable conditions of women suffering under the male dominance society, who is an object of gaze in the masochistic society where she is wife, a daughter, mother, an artist or a writer. Most of her characters are alienated from the world, from the society, from the families, from parents, and even from their own selves. Most of the novels by her are set among the cultural and social changes.

Anita Desai is indisputably one of the most powerful contemporary Indian novelists in English. She has been known as a literary genius both in India and abroad. She was born on June 24, 1937 in Missouri, a hill station near Dehradun in northern India, She grew up surrounded by Western literature and music. Her father D.N. Mazumdar was a Bengali and her mother Toni Nime was a German and met Mazumdar in Germany, then immigrated to Indian 1920s. Anita Desai was one of four children; she had two sisters and a brother. She spoke German because as she explains, her parents spoke German with each other. German therefore became her first language as a child. But she communicated with her friends and neighbours in Hindi.

Anita Desai's major works as a sincere writer are her first novel- Cry the Peacock 1963,Voices in the City -1965, Bye Bye Black Bird- 1971,Where shall We Go This Summer? 1975, Fire on the Mountain -1977, Fasting Feasting -1999. Besides this the fiction she has penned foe children includes The peocock Garden-1974, Cat on a house boat-1976, The Village by the Sea - 1982. She has two collection of short stories to her credit:Games at Twilight and other Stories - 1978, Diamond Dust and Other stories -2000. She has also contributed The peacock Garden - 1979 , Clear light of Day - 1980 , , In Custody -1984, Baumgartner's Bombay -1987 ,Journey to Ithaca -1995 , , ,The Zigzag way - 2004, Hill of Silver, hill of Lead -2005

Anita Desai is also a guide star for many bright young writers. If we start from home, like her own daughter Kiran Desai whose first novel, Hullabaloo in the Guava orchard was a distinguished debut in 1997, and her second novel, Inheritance of loss became a classic and won for her the famous Booker Prize. Kiran dedicated this novel to her mother, Anita Desai.

From the very beginning of the human civilization, Nature -Physical environment has been appeared as a primary source of living and income. As a free gift of nature, natural resources have been used and misused the way human being likes to use it, as a result natural resources are being degraded and gradually fading away the natural setting with the 
concern of the global threats revolving around us. With the passing of time, these natural resources are affected due to population, pollution and other avarices of human being. Now the writers come out with the global concerns for the degradation of nature and ecological landscapes. Anita Desai is one of the few Indian writers in English in the post colonial era who construct nature in their works. Anita Desai's characters are from the well to do sections of the Indian society like Nanda Kaul who is the wife of Vice Chancellor. And their problems are either psychological or spiritual not social or economical. They discuss issues like conformity and rebellion, attachment and detachment. Madhusudan Prasad comments on this novel:

In fact this novel deals, in the main, with the loneliness and isolation as well as the resulted anger and agony in the deserted life of Nanda Kaul, who presents an unforgettable, pathetic portrait of old age.

\section{Nanda Kaul}

Nanda Kaul had prepared herself for a long time to enjoy the peace and beauty of the lonely place Kasauli. The arrival of Raka appears to be a danger to her self-imposed seclusion. She wanted to be alone with nature but her isolation is to be intruded by one more strange character Raka.

She desires only to be left alone to pursue her own life amongst the rocks and pines of Kasauli. She is glad only when she is left alone to mount higher and climb on the top of it. Mrs Kaul is not an alien by nature or by birth. Her alienation is a thing thrust upon her by herself. She wants to live in solitude because she is fed up with the circumstances prevailing in her old house. There is symbolic end when the mountain has been set on fire.

In the Modern societies and also in the traditional Indian family, elderly women to be marginalized and so Anita Desai centres her novel on the character of an old woman, Nanda Kaul, who chooses a marginal place to lie in and she identifies herself with 'barrenness and starkness' of the surrounding landscape. Moreover Anita Desai can describe the human emotion in conjunction with not only their action but with the surroundings so well, as she did in her novel "Fire on the Mountain." Nature lovers will fall prey to the very first chapter of the book, as the author describes the Kausauli, the place where Nanda Kaul, the Protagonist is spending her best years of her life; the author depicts her character with everything around nature, how she influenced her surroundings and each at of hers defining her mental status 
so that we can read her mind. By the close reading of the novels of Anita Desai like where shall we go this Summer? and especially, in Fire on the mountain, one finds the connection between the nature and woman, and the importance of nature. During the post colonial era, Anita Desai is one of the few Indian authors in English who construct nature in their works. She remarkably writes on those aspects which she has observed. She succeeds in capturing and delineating the spirit of surroundings, places and social values.

Due to lack of attention and affection from her husband and family, she desires only to be left unaccompanied to pursue her loneliness amongst the rocks and pines of Kasauli. But there is not complete escape from the past memories as Nanda is also fail in her efforts. Desai has portrayed Nanda Kaul as a wife, mother, and grandmother who spent her whole life for her family, bringing up the children, and performing the all the household duties and responsibilities by ignoring her own desires, crushes, expectations, sacrifices etc and in short losing her own identity she merges with the family which is not expected as something extraordinary but considered usual in Indian context. The opening part of Fire on the Mountain depicts the geographical and Psychological setting of the protagonist Nanda Kaul to the arrival of Raka- her great granddaughter. Part II of the novel deals with the interaction and later on lack of it between Nanda Kaul and Raka. Despite the generation gap, they are quite similar in behaviour.

The novel deals with the marginal, unimportant, loneliness, isolation and agony in the life of the protagonist, Nanda Kaul. Nanda Kaul, a great grandmother, has renounced her entire world; living in isolation has come to Kausauli to spend her remaining days in the peace of mountain. It was her love for nature which brought her to the desolate place Carignano: the place of isolation and bareness as her past life was full of suffering and miseries. From the centuries, In India, male domination has remained as a powerful factor in familial relations. Naturally it implies sacrifice on the side of woman and not on the side of men. So Nanda Kaul has bitter experiences too. So she comes to the conclusion that it is better to be free from the shackles of life and wishes to breathe freely and move like a free bird. Here I think that at this age of Nanda Kaul, she is going through the Menopause period, but no one realizes her mental and physical condition. During this phase woman needs special care and affection. As per our Indian culture or Indian tradition, as a woman, she must continue to give every second of her life, but nobody aware about that in this crowded house, she felt isolation and loneliness. Due to dejection and rejection, she wanted to free from these forced relationship and from the monotonous motherhood. . As a result she is searching for her own identity. Woman is expected only to nurture others. So as a wife of 
Vice chancellor of Panjab University, Nanda Kaul was busy all the time with endless household works and societal duties. Like Virginia Woolf's character named Clarissa Dolloway, the wife of Vice chancellor, in Mrs. Dalloway, her life is also full of social duties and activities. Her distress as a busy wife is presented as;

"The old house, the full house, of that period of her life when she was the Vice Chancellor's wife and at the hub of small but intense busy world, has not pleased her. Its crowding had stifled her...too many trays of tea would have to be made and carried to her husband's duty, to her mother in law's bedroom, to veranda that was the gathering place for all... Too many meals, Too many dishes, on the table, too much to wash up after..." (fire on the Mountain, pp.29-30)

Unfortunately, Nanda Kaul and her Husband do not have an affectionate relationship. She is dutiful wife and mother but the relationship between husband and wife was unhappy. Infact, she is a submissive and due to her compromising nature, she ignores her husband's illicit relationship with Miss David. Her husband's extra marital affair with Miss David, the mathematics mistress which he carried lifelong whom he had not married because she was Christian but whom he had loved, all his life loved. He was such a coward that he could not even dare to break the social convention by marrying her. Unfortunately she bears it lifelong and suffers. The lack of affection and warm from her husband is one of the reasons for their unhappy married life as well as her trauma. Rather he considers her as a tremendous hostess of all the parties which he held, where the invitees are more women than men. Her husband did not give his love to her rather he had treated her as a decorative piece or machine which can be useful for the running of his household. She was continuously neglected and became lonely from inside. It has been clearer that Nanda Kaul's life has been purposeless and meaningless. Her own world, her own choice was gone somewhere, she is in the state of anxiety, therefore Seema Raizada states about her trauma, "We find that Nanda like many other characters of Anita Desai suffers from loneliness unfulfilling relationship. She weaves a world of her own; the waste in the landscape mirrors the waste of her life." (Raizada, 174) probably she suffered from nimiety (disorder) - unpredictable excess of the presence of family members and friends.

Nanda Kaul becomes a rebellion and protests against the forced relationship by freeing herself from the shackles of her married life. And becomes a part of nature and spends some time with her and indentifies her with tress, mountains and wind. But fate has one more test for her in old age. Raka- her great grand Daughter comes in Nanda's life. She 
has decided to live in a calm place; once again she is called for nurturing, caring, and comforting by her children. The news of the arrival of Raka upsets her. Both have secluded themselves from external world just like the isolated place Carignano. Due to violence of her drunken father towards her mother, unhappy and unhealthy relationship of her father and mother, insufficient parental care, she needs isolation and loneliness in her life. She feels insecure and solitude and wishes to live with nature. As she was suffering from typhoid, her mother decides to send Raka at Carignano with her grandmother as everyone tells her to go Kasauli, where nature works more than medicines do. Still People believe that nature can help us in every situation and we get solution from nature. So Raka comes to nature so by living with nature in peace and harmony she can be free from the typhoid.

On the other hand, Nanda Kaul does not have positive attitude on her arrival.

"Nanda is a recluse out of vengeance for a long life of duty and obligation; Raka is recluse by nature and instinct she had not arrived at this condition by a long route of rejection and sacrificeshe was born to it, simply..."

However to her surprise, Raka loves to be alone and pursue her secretes of life in the rocks and pines. Naturally she doesn't want anyone to enter in her paradise. She is living in fantasies. Desai has written this novel in unique manner with the symbolic interpretation. In this novel, Nature is used as a motif as she has blended the nature and characters. This novel is rich with the images of woman nature interconnectedness. Desai exhibits several dominant zoological, botanical atmosphere and colourful imagery through the description of landscape, jackal, and imagination of nature, and Desai skilfully draws a meaningful link between human and nature to create a mosaic touch in the novel. By mentioning the efficiency of forest fire, Anita Desai tries to emphasis on the ecological imbalance on earth due to human beings misused of it. By using the metaphors of insects and animals like mosquitoes, lizards and jackals, Anita Desai draws our attention on how her female characters loathe the absurdity of their existence.

In fire on the mountain, Desai symbolises, Nanda Kaul as a Mountain or forest which signifies her self -esteem and Raka represents as a wild nature or fire as well as their mental trauma. So by the arrival of Raka, her life becomes hell.

The novel also depicts the darker sides of nature as well as the darker aspects of the women concerned through lla Das's Rape and how she was killed though in her whole life she serves the human society. Similarly, the Nature servers the society and by the side of it 
is destroyed or oppressed by men which shows the domination and exploitation of women and nature.

From the ecofeminist perspectives, the violation and rape of the women is linked with the violation and rape of the earth, and it's evident is, The Pasteur Institute, in this institute, they used animals for their researches; "they have rabbits and guinea pig there, too many animals. They use for tests... they empty the bones and ashes of dead animals down into the ravine.."(pp.44)

When the news of Ila Das's tragic death is transmitted to Nanda Kaul by the phone call as is her arrival, she is terribly stunned, shocked and shattered. She is unable to believe that her friend would end up like this. It is unbearable and worse. Nanda breaks down and wants to cry but cannot make a sound. By not inviting lla to move with her, Nanda becomes real culprit for the attack on her friend. And she is depressed and suppressed in her heart by the shocking news of her friend's rape and death which leads her too towards the death. Here Fire highlights the mental trauma of Nanda Kaul and Raka. At that very moment, Raka returns home, excitedly informs her about the setting of the fire to the forest,

"Look nani, I have set the forest on fire. Look Nani look - the forest is on fire."

R. S. Sharma opines that "the fire consumes the fictive world of Nanda Kaul and leaves the reader smouldering under the impact of a tragic awareness that he had never anticipated. The only reality of fire symbolizes the funeral pyre- the ultimate consummation. Apparently, Raka is only survivor of this three woman story and she is identified with the triumphant knowledge. "

This fire (the constructive and destructive force) symbolises the characters of Raka and Nanda Kaul and Ila Das as strong and at the same time as purifier. As by the dreadful death of lla das who was raped and murdered, set fire in Nanda's heart. By setting a fire everything will be destroyed so Nanda Kaul also wants to set fire to her life and wants to find a new life.

Anita Desai thus, occupies an unassailable place in the galaxy of Indian English women writers. She is recognized as one of the strongest feminist voices in India today. In this wonderful novel Desai has pierced into the prized solitude of a regal, dignified, elderly woman, and given us a look inside her heart who makes us "... understand and feel what is to be woman, know how a woman thinks and feels and behaves." 
Towards Excellence: An Indexed, Refereed \& Peer Reviewed Journal of Higher Education/ Ms. Anjali Parmar \& Prof. Ami Upadhyay / Page 152-161

(Desai Anita, "Indian women writers, The Eye of the beholder Indian Writing in English,ed.Maggie Buthcher(London: commonwealth Institute,, 1983)pp. 54) 


\section{References}

Adhikari, Madhumalati. "Violence Against Women; Inscription in Anita Desai's Novels." Edited by .K.K. Sharma, 1998, vol.5, no.1, pp.68.

Agarwal, Malti. New Perspectives on Indian English Writing. New Delhi, Atlantic,2007.

Bande Usha. The novels of Anita Desai: A study in Character and Conflict. New Delhi: Prestige books, 1988.

Bhatnakar M.K, editor. Indian Writing in English. V-I Atlantic Publishers and Distributors: New Delhi, 2001.

Beaviour,Simon, De. The Second Sex. Penguin Hammondesworth,1982, p.32.

Bhatnakar M.K, editor. The Novels of Anita Desai: A Critical study. Atlantic Publishers and Distributors, New Delhi, 2000.

Desai Anita, Fire On the Mountain. Random House India, Noida, 2008.

Dubey, P.D. Feminine Consciousness in Anita Desai's Fire on The Mountain, Critical Essays on Anita Desai's Fiction. Edited by Jaydeep Singh Dodiya,IVY publishing House, New Delhi,2000.

Griffin, Susan. Woman and Nature: The Roaring Inside Her. Counter point, 2000.

Kumar, Brajesh . "Feminist Perspectives in the Novels of Anita Desai: critical Responses to Feminism." Edited by Binod Mishra, Sarup \& sons, New Delhi, 2006,pp6472,print.

Prasad Madhusudan. Anita Desai the Novelist. New Horizon, Allahabad, 1981, pp.125.

Raizada, Seema. "Strategic Presence of Raka in the Narrative of Fire on the Mountain; in the fiction of Anita Desai." Edited by Suman Bala and D. K. Pabby. New Delhi,2002, vol.1, pp.174-179.

Sharma, Krishna. Anita Desai- the Sexiest Nature of Sanity: The Women in Indian Fiction in English. Asia Publishing House, New Delhi, 1982.

S. Indira. Anita Desai as an Artist. New Delhi, Creative Books, 1994.

Shyamala, C. G. "Nature and Ecocriticism in Cry the Peacock and Fire on the Mountain." The Criterion, An international journal in English, 2011, vol.2,no.3,pp.1-9.

See the blurb on "Biography: Anita Desai" Accessed on 25 2 th 2015.

Tandon Neeru. Anita Desai and Her Fictional world. Atlantic publishers and Distributors, New Delhi,2008. 
Wier,Ann Lowery. "The Illusions of Maya: Feminine Consciousness in Anita Desai's Cry the Peacock." Journal of South Asian Literature, 1981, vol.16.no.2,pp.14.

www.bestjournals.in

www.ijelh.com

www.languageinindia.com/may2013/shaukatdeaialienationfinal.pdf

www.literary quest.org

Anjali Daud Parmar

Ph.D. Scholar, Asst.Prof.

Gujarat Technological University, Ahmedabad

\&

Prof. Ami Upadhyay

Director, School of Humanities \& Social Sciences

Dr.Babasaheb Ambedkar Open University, Ahmedabad 